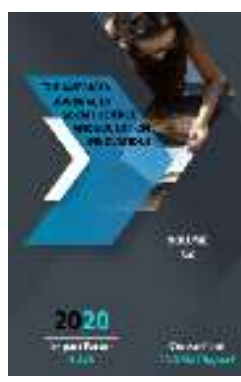

Journal Website: http://usajournalshub.c om/index,php/tajssei

Copyright: Original content from this work may be used under the terms of the creative commons attributes 4.0 licence.

\section{Methods Of Educating Youth In The Spirit Of Patriotism, Physical And Intellectual Devotion To The Motherland}

\author{
Akhmatkulov Umidjon Makhamadjonovich \\ Teacher Of The Faculty Of Military Education, Fergana State University, Uzbekistan \\ Abdullayev Bakhriddin Tojialiyevich \\ Teacher Of The Faculty Of Military Education, Fergana State University, Uzbekistan \\ Tojiyev Khakimjon Kholikovich \\ Teacher Of The Faculty Of Military Education, Fergana State University, Uzbekistan
}

\title{
ABSTRACT
}

Improving the effectiveness of education to ensure that the person is at the centre of education and young people receive an independent education, they are well prepared in educational institutions and, in addition to solid knowledge in their field, possess modern pedagogical technologies and interactive methods. we need teachers who know the rules of use when organizing reading and educational activities. To do this, it is necessary to equip all-natural science teachers with new pedagogical technologies and interactive methods, apply the knowledge gained in teaching and educational activities, and constantly improve their qualifications. Today, the use of new pedagogical technologies in education is becoming increasingly important. It is known that pedagogical technology is intended for the educational process and determines the goal of the process of personality formation in society. The pedagogical system needs updating as society changes. The "National Program for Personnel Training" set the goal of education in a new direction: "to get rid of the ideological stigma of the past, to train highly qualified personnel that meet the highest moral and ethical standards at the level of developed democracies". That is, today it is necessary to completely update the content of pedagogical technology, the goal of teaching, and the improvement of the pedagogical process. Education-based on advanced pedagogical technologies with the skilful use of traditional teaching methods is a requirement of our time. The main goal of reforming the education system is to develop students' ability to think independently, use modern information tools and teach them to apply their knowledge to solve any problems.

\section{KEYWORDS}

Patriotism, physical education, education of youth in the spirit of military patriotism, new methods, pedagogical technologies. 


\section{INTRODUCTION}

Today, there is a growing interest in the use of interactive methods, innovative technologies, collaborative learning technologies in the educational process. Until now, in traditional education, students were taught to acquire only ready-made knowledge, while modern technologies allow them to search for, independently study and analyze the knowledge they acquire, and even draw their conclusions. to produce. Pedagogical technology is an individual process that is goaloriented, pre-designed, and guaranteed based on the needs of the student [1-4].

Youth is the future of our Motherland, our nation. As we entrust the fate of our country to them, first of all, they must deeply understand the complex and responsible task entrusted to them and contribute to it. After all, love for the Motherland, love for it is directly determined by the creative work of everyone in the development of this country. In the development of national identity, the education of thoughtful young people, imbued with the ideas of national patriotism, is of great importance. Therefore, each of our young people preparing for the defence of the Motherland must be brought up in the spirit of high patriotism. Patriotism is high human quality. Patriotism is one of the brightest aspects of perfection. That is why it is called in Hadith, "Loving one's country is faith." However, it should be noted that today's generations of people, who in the past made a huge contribution to world civilization, their heritage is recognized by the peoples of the world, because such feelings lead to national pride and spiritual perfection, strengthen the desire to understand national identity. Military patriotic education gives good results only when it is carried out in a way that is inextricably linked with physical education.

Therefore, military-patriotic education cannot be imagined without physical education. Tolerance to cold and heat, not to succumb to diseases quickly, to overcome difficulties, willpower. The role of physical education and sports in the development of students - young people and teachers - the qualities of the Defender of the Fatherland, such as perseverance, the ability to move fast and agile, is enormous. One of the urgent tasks of today is to educate young people in the spirit of patriotism, to prepare them physically and spiritually for the defence of the Motherland. Training of students in general education institutions, secondary special and secondary vocational education institutions, including students studying in higher education institutions in the spirit of military patriotism, is now carried out through all systems of educational work. Indeed, true devotion to the Motherland requires the ability to defend it as well. Educating students in the spirit of military patriotism should play a key role in all types of educational institutions [5,6].

\section{MATERIALS AND METHODS}

Our government pays special attention to educating young people spiritually, physically and intellectually in the spirit of patriotism. We can see this from the government's decrees and decrees in this area. In particular, to increase and intensify the work on educating young people in the spirit of military patriotism, the Cabinet of Ministers in 2018 Resolutions No. 140 of February 23, 2020 "On approval of the concept of military-patriotic education of youth", No. 369 of June 10, 2020 "On measures to further increase the effectiveness of patriotic education of youth" $[7,8]$ and the main tasks are as follows:

- To educate young people in the spirit of the national idea and devotion to the Motherland, to instil in their hearts and minds that the defence of the Motherland is an honourable and sacred duty;

- Pride in our ancient history and culture, the selfless struggle for the independence and 
development of our native Motherland, the formation of a sense of belonging to them, strengthening confidence in the strength and potential of our national army;

- Strengthening the understanding of the need for physically strong and spiritually mature youth in our national army, the fact that military service is a sacred duty for every citizen of Uzbekistan, as well as theoretical and practical skills in this area;

- Formation in young people of skills to approach the political and social processes taking place around us and in the world based on our national interests, ideological immunity against various internal and external threats;

- Training of young people with the ability to make quick and independent decisions in any complex situation, the effective use of modern military equipment;

- To be ready to defend the interests of Uzbekistan not only in the military sphere but in all spheres of life, to be selfless for the country - to instil in the minds of young people through real-life examples and effective means.

Pre-conscription training is the most important component of the system of training young people for service in the Armed Forces of the Republic of Uzbekistan, training defenders of the homeland. In public education, schools must provide a high level of pre-service training and military-patriotic education so that students can master the rules of education in the educational process. It is necessary to have the necessary knowledge and practical skills on the Constitution of the Republic of Uzbekistan, government decrees, the basics of military work to defend the homeland, and young conscripts to acquire modern weapons and military equipment in a short time. The quality of pre-conscription training, its educational significance, the military rank and pedagogical qualifications of a military leader are directly related to the ideological and political maturity of his methodological skills. The fulfilment of these tasks is directly related to the mature system and methodology of training, effective means of education, well-organized leadership on a scientific basis. The educational process of pre-service training is planned and organized by the military leader in accordance with the Science Program, orders, normative documents and educational-methodical recommendations of the Ministries of Public Education and Defense of the Republic of Uzbekistan [9,10].

In these programs, military education subjects are identified, time is divided into disciplines (sections), types of training, study assignments, literature, etc. is displayed. According to our ideology, didactics considers the education of students as a complex sociopedagogical process. The main tasks of the process are:

- $\quad$ General education (equipping students with knowledge, skills, abilities);

- $\quad$ Educational (formation in students of personality and military team qualities necessary for the future defender of the Motherland);

- Developmental (formation in students of the ability to take a creative approach to solve problems);

- Psychological training (formation in students of psychological preparation for successful actions in modern warfare).

Implementing these tasks in a limited unit is an important factor for a comprehensive approach to student preparation. In the pedagogical sense, the educational process consists of the purposeful, interconnected activity of the educator (military leader), which is called teaching to the learners (subordinates) called teaching. The main role in this process belongs to the educator (military leader). Its main pedagogical tasks are:

1. Organization and management of the educational process in schools; 
2. Provide training material in one system and demonstrate the most appropriate ways to work with armaments and equipment;

3. Develop students' interest in education and other positive aspects of education;

4. Students acquire knowledge, skills, abilities, abilities and improve their skills independently;

5. Assessment of students' readiness, assessment of knowledge, skills, abilities and professional qualities.

At the same time, the use of effective methods in organizing the learning process has its characteristics. First of all, the existing military training course includes 8 independent disciplines:

1. Practical physical training.

2. Shooting training.

3. Civil defence.

4. Basics of military education.

5. Basics of military service.

6. Medical and sanitary training.

7. Introduction topic.

\section{Control exercises.}

Each of these requires carefully thought-out planning in a school system unit, logically and methodologically. Also, pre-service training is planned and conducted separately for adolescents, and medical training is conducted separately. In secondary special and vocational schools, study groups of not less than 8 girls (adolescents) are fully engaged in programs for adolescents (girls). It is planned to hold weekly military-sports classes outside the classroom, show military-educational and military-patriotic films once a month, as well as classes in clubs and optional courses.

\section{Forms And Methods Of Pre-Service Training And Their Description.}

It is based on the achievements of militarypedagogical science and its componentdidactics. Didactics (Greek teacher) is a branch of pedagogy that develops the theory of education and information. Military didactics is a branch of military pedagogy that develops the theory of military education and information. It teaches the laws of the educational process, formulates principles, defines and observes methods, explores the educational value of education, and identifies information knowledge, skills and abilities, processes, outcomes, and tools more effectively. The process and outcome of knowledge is the acquisition of knowledge, skills and abilities. The main way to get information is education. The process of imparting and mastering knowledge, skills, abilities and cognitive activities is a two-way process: on the one hand the educator (teaching) and on the other hand the learner (reading) teaching and learning are closely interrelated and the success of teaching is equally two-way movement and maintenance. one cannot teach what one does not want to read. This means that the learning process should be built in such a way that it can arouse interest in students. The main content of the educational process is to impart knowledge and mastery. If knowledge forms the basis of practical activity, it identifies abilities and skills.

Hence, the second feature of the content of the educational process is, in essence, the imparting and mastering of skills and abilities that apply knowledge in practice. In-depth theoretical training should be reinforced with high practical skills. The main form of organization of educational work is a course in which students receive theoretical knowledge.

Good organization of the lesson, holding it in an interesting and visual, highly ideological and scientific exhibition is a mandatory requirement for every teacher. In addition to 
theoretical lessons with the military leader group, practical training in military rooms and places, shooting, tactical exercises, military sports games, excursions (to museums of military units), march to the places of the Uzbek people's revolution, war and labour glory, organized educational films theatre The performances are widely used.

A class (theoretical) lesson is a type of lesson that can be solved and at the same time, some mental and sensory skills can be formed. The main requirements of each such training should be a high ideology, close connection with life and practical activities of students. Classes are conducted to learn unit rules, firing theory, parts of weapons and equipment, basic knowledge of weapons of mass destruction, and several special and military-technical training questions. There are the following main types of pre-service training courses:

1. A course to impart new knowledge to which theoretical information is given.

2. The course of strengthening knowledge and skills is held in the form of practical training, place, marching platform, military room.

3. Knowledge and skills test lesson. It includes oral question-and-answer, theoretical (written) work or practical exercises (field trip, performing methods with a weapon, etc.), control work and exercises.

4. The joint course is the most common type of course in the military education system, it forms all or a part of the characteristics of other types of courses: imparting new knowledge, testing, consolidation, etc.

The program of pre-service training of teenagers includes theoretical, practical, exemplary, tactical, tactical - pure control exercises. Theoretical classes (lectures, conversations) are conducted in the form of oral narratives, which provide the basis of scientific knowledge in the field of study, reveal complex questions of dialectical interrelationship, help students develop creative thinking and form a correct worldview, current issues of theory and practice. , should reflect the modern achievements of science and be the basis for the organization and conduct of other types of activities and independent work of students.

The training are held to demonstrate the best organizational methods, armament, military equipment, the most effective methods of using engineering equipment, as well as to acquaint students with the location and life of military personnel, armament and combat equipment.

The practical training is aimed at mastering the methods of armaments, tools and combat equipment, their application, use and storage, development of certain skills and performance of various methods and actions, consideration of other issues in accordance with the normative and educational program. In the practical classes, the knowledge and skills acquired with students are improved, the practical work of each student in the educational institution is its main content. The final stage of practical training is practical training. They are usually held locally. In tactical training, students are taught the skills and abilities of a soldier, an observer to perform practical duties in a combat environment, training questions are developed in an orderly manner according to a well-thought-out plan and tactical conditions. Control classes are held to determine the level of knowledge and practical skills of students with the issuance of final grades. Written work is one of the forms of control, which not only tests the mastery of the material covered, but also the ability of students to express their ideas correctly, to perform a specific task. Lessons that require written answers to questions or programmed control tools can be used as answers in the lesson. 


\section{CONCLUSION}

In short, a new definition of the content of education based on modern pedagogical technologies, the preparation of new forms and methods of education, including all disciplines, situational texts to include in the content of disciplines in the field of educating young people spiritually, physically and intellectually. Improving the system of problem characters, tests, and the formation of professional qualities in the individual through a direct demonstration based on a system of distance learning on new methods, not to master their spiritual qualities. It is a modern requirement to develop a system of assignments, to determine the level of mastery of students as a result of training and lessons based on new pedagogical technologies, to develop and update the system of objective assessment.

\section{REFERENCES}

1. Farsakhanova, D. (2020). Improvement of the methodology of spiritual and moral education of students of pedagogical institutions. Архив Научных Публикаций JSPI, 5(1). извлечено от https://science.iedu.uz/index.php/archive jspi/article/v iew/480.

2. Nasriddinov Ch.R. Military psychology. Tashkent. "Fan" publishing house, 2004.

3. Sadulla Otamurodov, Sarvar Otamurodov. Spiritual revival in Uzbekistan. Tashkent. New Age Generation Publishing House, 2003.

4. Fundamentals of military-patriotic education. Marifat Publishing House, 1988.

5. E.Umarov, M.Abdullaev. Fundamentals of spirituality. Sharq Publishing House, 2005

6. Instructions of the Minister of Defense of the Republic of Uzbekistan D-7, D-16, D-17. 2003
7. The Cabinet of Ministers. (2018, February 23). 140-son 23.02.2018. On approval of the concept of educating young people in the spirit of military patriotism. Lex.Uz. https://lex.uz/docs/3571158.

8. The Cabinet of Ministers of the Republic of Uzbekistan. (2020, June 10). 369 No. 10.06.2020. On measures to further increase the effectiveness of patriotic education of young people. Lex.Uz. https://lex.uz/docs/4850220.

9. Inoyatov I.Yu., Abilov M.Kh. "Sacred corner of the homeland" Tashkent. "Uzbekistan". 2001

10. Republican Center for Spirituality and Enlightenment "A free and prosperous life is impossible without high spirituality." Tashkent. "Uzbekistan". 2006 